\title{
Accounting
}

\section{Impact of land-acquisition induced resettlement policy on the ethnic household income in mountainous Vietnam}

\author{
Nguyen Lam Thanh ${ }^{a}$, Nguyen Anh Phong ${ }^{\text {b* }}$ Vu Huy Phucb, Pham Thi Thu Ha ${ }^{b}$, Nguyen Mai Linh \\ Le Ngoc Minh ${ }^{b}$ and Nguyen Phung Quanc
} \author{
${ }^{c}$ Committee for Ethnic Minority Affairs, Vietnam

\section{H R O N I C L E} \\ Article history: \\ Received: September 25, 2020 \\ Received in revised format: \\ September 302020 \\ Accepted: November 7, 2020 \\ Available online: \\ November 8, 2020 \\ Keywords: \\ Land acquisitions \\ Resettlement policy \\ Ethnic household \\ Household income \\ Mountainous area \\ Vietnam
}

${ }^{a}$ Ethnic Minority Council, Viet Nam National Assembly, Vietnam

${ }^{b}$ Institute of Policy and Strategy for Agricultural and Rural Development, Ministry of Agriculture and Rural Development, Vietnam

\section{Introduction}

Resettlement is carried out due to the land acquisition for national or local community purposes, such as industrial zones, public works, new rural residential areas, forest protection and development, and especially reservoir constructions for irrigation and hydropower which have a large number of people directly affected, of which, $90 \%$ are ethnic minorities living in mountainous areas (Ministry of Agriculture and Rural Development, 2014). In the whole country, there are 152 hydropower and irrigation projects in 34 provinces involving in resettlement until 2020. Among them, 77,429 households have finished their resettlement, accounting for $95.1 \%$ of total households needed to be resettled. It is estimated that $81.7 \%$ of resettled households participated in concentrated resettlement, while $18.3 \%$ are scattered resettlement; and among these resettled households (Ministry of Agriculture and Rural Development (2017); Ministry of Agriculture and Rural Development (2020)).

\footnotetext{
* Corresponding author.

E-mail address: phong.nguyen@ipsard.gov.vn (N.A. Phong)

\begin{abstract}
Land acquisition and resettlement issues related to hydropower and irrigation works have always been one of the hot issues in Vietnam mountainous areas for many years. Although the Government has introduced many policies to ensure the rights of resettled people, as well as protect their lives, the effectiveness of these policies seems to be still insignificant, because many resettled people still face many difficulties in their daily life, especially income. The research is conducted within the
project titled "The urgent issues in resettlement implementation for the ethnic minorities in Vietnam mountainous areas" and funded by National Council for Science and Technology Policy in 20162020 (CTDT/16-20) under Committee for Ethnic Minority Affairs. Applying Likert-scale and Propensity Score Matching (PSM), this study shows that $34 \%$ of the resettled households have a lower income, specifically estimated to be 8.0 - 13.1 million VND/household/year or 1.7 - 3.0 million $\mathrm{D} /$ person/year lower than the income of the controlled group. However, agricultural income is focuses on clarifying the impact of the resettlement policy on the general income and agricultural income of ethnic minority households; while methods to create jobs, increase income, and reduce poverty sustainably for ethnic minority households in the resettlement sites should be conducted in another research in the future.
\end{abstract}


The Government policies on implementing land acquisition and resettlement always focus on the principle that the new living of resettled people must be ensured to be at least similar to before resettlement. However, some summaries that reflect the effectiveness of the resettlement program over the years indicated that numerous shortcomings are maintaining in the implementation process of the Government's resettlement policies (Committee for Ethnic Minority Affairs (2014); Ministry of Agriculture and Rural Development (2020)). So, do these shortcomings affect the income of resettled people? To answer this question, the research team has conducted a study for two years during 2018-2019 in 10 mountainous provinces that involve in concentrated resettlement. The study result is used for clarifying the actual impact of resettlement policy on ethnic minority households.

\subsection{Literature review}

Resettlement has myriads of negative impacts on local communities, such as lack of residential land, production land, public infrastructure, and livelihood (Thanh, 2004). Although resettlement provides new production sites, these places tend to be separate from the residential area. Besides, not all of the resettled households get enough production land. Even having enough land, its quality is not fully adequate with the previous one, which brings difficulties in producing agricultural products, then affects the household income (Nguyễn, 2009). Even in one of the most national key hydropower projects as Son La hydropower, the resettled people still lack production land, specifically, a low amount of 0.22 ha/household for agricultural land and 0.84 ha/household for forestry land on average (Nguyễn, Nguyê̂n, Trang, \& Nguyễn, 2011).

The causes for causing the above situation seem to be:

- The capital for supporting the livelihood of the resettled people is not adequate (Lã, 2009). Most of the projects focus their capital on infrastructure construction, while neglect livelihood support for resettled people. The income restoration process needs long-term support; however, current policies have not mentioned a compulsory requirement towards projects for long-term support. It is a fact that there is no sustainable financial source ensuring support for a long time after completing relocation.

- The resettlement planning does not pay much attention to the consequences that the resettle people must face, which causes the lack of land, jobs, and trading sites and makes these people become poorer (Phạm, 2015; Nguyễn, 2014; Nguyễn, 2015). Indeed, the resettlement areas are usually far from the center and not fully invested with transportation infrastructure, which results in obstacles for both daily movements to the center and transaction development.

- The neglect of Local Government or the poor coordination between the Local Government and project investors in guiding income restoration methods for the resettled people lead to a negative impact on their living (Nguyễn Tiến Dũng \& Đặng Khắc Ánh, 2016).

- The education and training capacity of the resettled people is not high, which causes food security problems, income decrease, unemployment increase, and expansion of social issues (Nhung \& Thang, 2017). The low capacity also leads to the ineffective usage of compensation money, which indirectly makes the households lack resources for their economic development.

Most of the current studies on the resettlement analysis in Vietnam are qualitative studies, while there are not much of quantitative studies. The current quantitative studies on impact assessment of resettlement policies tend to apply common econometric methods as Ordinary Least Square (OLS) regression (Bui, Schreinemachers, \& Berger, 2013), Cronbach Alpha reliability assessment, and exploratory factor analysis (Nguyễn, Đào, \& Từ, 2016). However, these study results only help to identify the main impact factors without estimating the income gap between resettled households and unaffected households.

The most popular impact assessment method is the Propensity Score Matching (PSM). This method is introduced by Rosenbaum and Rubin (1983), then developed by Becker and Ichino (2002) and Khandker, B. Koolwal, and Samad (2009). The core of this method is comparing the treated and controlled group basing on propensity score which can be calculated from observed characteristics. Although PSM is an effective method, it has not been applied to compare the resettled group and the controlled group, especially in a wide range of many resettlement projects in the country. Therefore, this study will focus on filling this research gap.

\section{Methodologies}

This study performs the following sampling steps:

- To choose 10/34 typical provinces involving in hydropower and irrigation resettlement programs, of which, Son La and Lai Chau are in the Northwest region; Tuyen Quang in the Northeast region; Thanh Hoa and Nghe An in the North Central Coast; Quang Nam and Binh Thuan in the Southern Central Coast; Gia Lai and Lam Dong in the Central Highlands, and Binh Phuoc in the Southeast.

- In each selected province, the districts and communes involving the resettlement program for ethnic minorities were chosen. There are two groups selected in these research sites including the resettled group and the unaffected group, which are the people 
living in the neighboring communities with the resettled group but not affected by resettlement. These two groups are both interviewed by structured questionnaires consisting of contents necessary for assessing the resettlement impact on economics, social, and living environment. However, it should be noted that in the scope of this article, only the economic side will be selected to represent.

The selection of resettled and unaffected groups was random based on the household lists provided by the Local Government. In each list, the households were numbered from 1 to the end. Then, the research team used a random function in Excel for choosing exactly which households would participate in the interview. In case a selected household did not want to participate, the next random households would be replaced.

The total number of surveyed households includes 1,110 resettled households and 1,200 unaffected ones. However, after cleaning the answer sheet, checking the completeness and reasonableness, only 751 cases of the resettlement households and 816 of the unaffected households (accounting for $67.7 \%$ and $68.0 \%$ of the interviewed households, respectively) were kept for analysis. Specifically, the sample size is in Table 1.

\section{Table 1}

The sample size used for the PSM model

\begin{tabular}{lccc}
\hline Provinces & Resettled households & Unaffected households & Total by provinces \\
\hline Son La & 108 & 111 & 219 \\
Lai Chau & 81 & 120 & 201 \\
Tuyen Quang & 48 & 126 & 174 \\
Thanh Hoa & 49 & 66 & 115 \\
Nghệ An & 94 & 54 & 148 \\
Quang Nam & 59 & 27 & 86 \\
Gia Lai & 70 & 12 & 82 \\
Lam Dong & 118 & 51 & 169 \\
Binh Thuan & 75 & 171 & 246 \\
Binh Phuoc & 49 & 78 & 127 \\
\hline Total samples & $\mathbf{7 5 1}$ & $\mathbf{8 1 6}$ & $\mathbf{1 , 5 6 7}$ \\
\hline
\end{tabular}

The study applied a 5-scale Likert which is a popular technique introduced by Likert (1932), which is useful for measuring people's attitudes. In this study, the scale is used for measuring the resettled households' attitude towards the income change compared to before resettlement. Of which, the rank from 1 to 5 represents the respective meaning as follows: Greatly Lower, Lower, Same, Higher, Greatly Higher. Then, the responses were summarized and calculated on both the provincial and national average. The project-impact assessment on households' income compared to the controlled group has been recommended to apply the PSM model by Baker (2000), Ravallion (2001), Becker and Ichino (2002), Caliendo (2009), Caliendo and Kopeinig (2008), Khandker et al. (2009), Heinrich, Maffioli, and Vazquez (2010). The specific steps for this method are as follows:

- Step 1: To collect similar information from the resettled and unaffected groups, which enables to compare the similarity in Step 3.

- Step 2: From the survey data, to run a Logit regression model with $Y(1,0)=\beta_{0}+\beta_{1} X_{1}+\beta_{2} X_{2}+\cdots+\beta_{n} X_{n}$, where $Y$ is the dependent variable (having the value of 1 if the respondents are resettled households, while equal to 0 if being unaffected ones), $\beta$ is the coefficient and $X_{i}$ is the independent variables that are detailed in Table 3.

- Step 3: From this model, the propensity score is the probability of being a resettled group. This indication has the range from 0 to 1 . If a household has a similar propensity score to another one, these two households are considered to have similar characteristics. The calculation function is as follows:

$$
P_{\text {score }}=\frac{1}{1+e^{-\left(\beta_{0}+\beta_{1} X_{1}+\beta_{2} X_{2}+\cdots+\beta_{n} X_{n}\right)}}
$$

- Step 4: Identify the common support for comparison. The impact is estimated from the difference between pairs of resettled and unaffected households with the similarity in observable factors (or propensity score). There are three matching techniques applied in this research, including Nearest-neighbor matching, Radius matching, and Kernel matching.

Nearest-neighbor $(\mathrm{NN})$ matching: The resettled households are matched with the affected households having the most similarity. Specifically, an $i$ resettled household will be matched with a $j$ unaffected one having the nearest propensity score to the $i$ household.

$\min \|\mathrm{pi}-\mathrm{pj}\|$

Radius matching: An $i$ resettled household will be matched with a $j$ unaffected one having the nearest propensity score to the $i$ household but in a specific radius. This matching will reduce the bias caused by NN matching in case the propensity score distance within a matching pair is too wide.

$\|$ pi - pj $\|<$ r 
Kernel matching: An $i$ resettled household will be matched with a weighted average of all $\mathrm{j}$ unaffected ones, while weight and propensity score distance within a matching pair have an inverse relationship. The weight is calculated by the functions:

$$
w(i, j)=\frac{K\left(\frac{p_{j}-p_{i}}{h}\right)}{\sum_{j=1}^{n_{0}} K\left(\frac{p_{j}-p_{i}}{h}\right)}
$$

In which, $\mathrm{h}$ is a smoothing parameter called bandwidth, which is used to compute the common weight for all of the matchings.

- Step 5: To calculate the Average Treatment Effect (ATE)

ATE is the difference in the outcome (such as income, expenditure...) between the two groups and calculated by the functions: $A T E=$ The average outcome of the resettled group - The average outcome of the unaffected group,

where the resettled and affected groups will be identified based on different matching methods, which means each different matching method will result in a different ATE value. After that, a simple t-test will be applied to checking if the ATE has a significantly statistical meaning or not. In case the ATE has significantly statistical meaning, especially across matching methods, it can be concluded that there is a real difference between the two groups.

\section{Findings and Discussion}

\subsection{The impact assessment of the resettled households on their income measured by the Likert Scale}

$714 / 751$ respondents are giving their assessment on the current income compared to before resettlement, accounting for $95.1 \%$ of the sample. The average response was 2.854 with a standard deviation of 0.916 (Table 2 ). This average shows that the resettled households seem to have a lower or similar income compared to before resettlement because 2.854 stays between 2 and 3 - the value representing for Lower and Same income, respectively. The lowest assessment was found in Quang Nam with an average of 2.377, and the highest in Binh Thuan with an average of 3.365.

\section{Table 2}

Descriptive statistics: Impact assessment on the income

\begin{tabular}{|c|c|c|c|c|c|}
\hline Provinces & $\mathbf{N}$ & Min & Max & Mean & Std. Deviation \\
\hline Binh Phuoc & 47 & 1 & 5 & 3.085 & 0.905 \\
\hline Binh Thuan & 74 & 2 & 5 & 3.365 & 0.821 \\
\hline Gia Lai & 70 & 1 & 5 & 3.057 & 1.006 \\
\hline Lai Chau & 80 & 2 & 4 & 2.688 & 0.880 \\
\hline Lam Dong & 116 & 1 & 5 & 2.897 & 0.715 \\
\hline Nghe An & 91 & 1 & 4 & 2.626 & 0.839 \\
\hline Quang Nam & 53 & 1 & 4 & 2.377 & 0.713 \\
\hline Son La & 86 & 1 & 5 & 2.860 & 1.139 \\
\hline Thanh Hoa & 49 & 1 & 4 & 2.796 & 0.935 \\
\hline Tuyen Quang & 48 & 1 & 4 & 2.729 & 0.869 \\
\hline Total & 714 & 1 & 5 & 2.854 & 0.916 \\
\hline
\end{tabular}

Source: Authors' calculation from the survey in 2018-2019

The rate of having a lower income is considerably high (Fig.1), which is 38\% (34\% with the assessment of 'lower' while $4 \%$ with 'greatly lower'). Lai Chau has the highest proportion (59\%) of resettled households assessing that they have a lower income, the next ones are Nghe An (56\% including 54\% of 'lower' and $2 \%$ of 'greatly lower') and Quang Nam (56\%, including 47\% of 'lower' and $9 \%$ of 'greatly lower').

There are $36 \%$ of resettled households having an unchanged income compared to before resettlement, of which, Lam Dong gets the highest rate of 59\%, while Son La owns the lowest rate of $15 \%$. Only $26 \%$ of resettled households indicated that they have a higher income (including 23\% of 'higher' and 3\% of 'greatly higher'). Among provinces, Son La has the highest rate of higherincome assessment (40\%, including 38\% of 'higher' and $2 \%$ of 'greatly higher'). The next one is Binh Thuan (39\%, including $30 \%$ of 'higher' and $9 \%$ of 'greatly higher'). It should be noted that Son La, the province with the highest rate of higher-income assessment, still has a significant lower-income assessment (44\%, including 31\% of 'lower' and 13\% of 'greatly lower'). Binh Thuan although not having 'greatly lower', still has $12 \%$ of 'lower'.

This Likert Scale result implies that a large part of resettled households has a lower income compared to before resettlement. However, it is still not clear if this income gap between the two groups is significant or not. Therefore, the PSM model should be applied to answer these questions. 


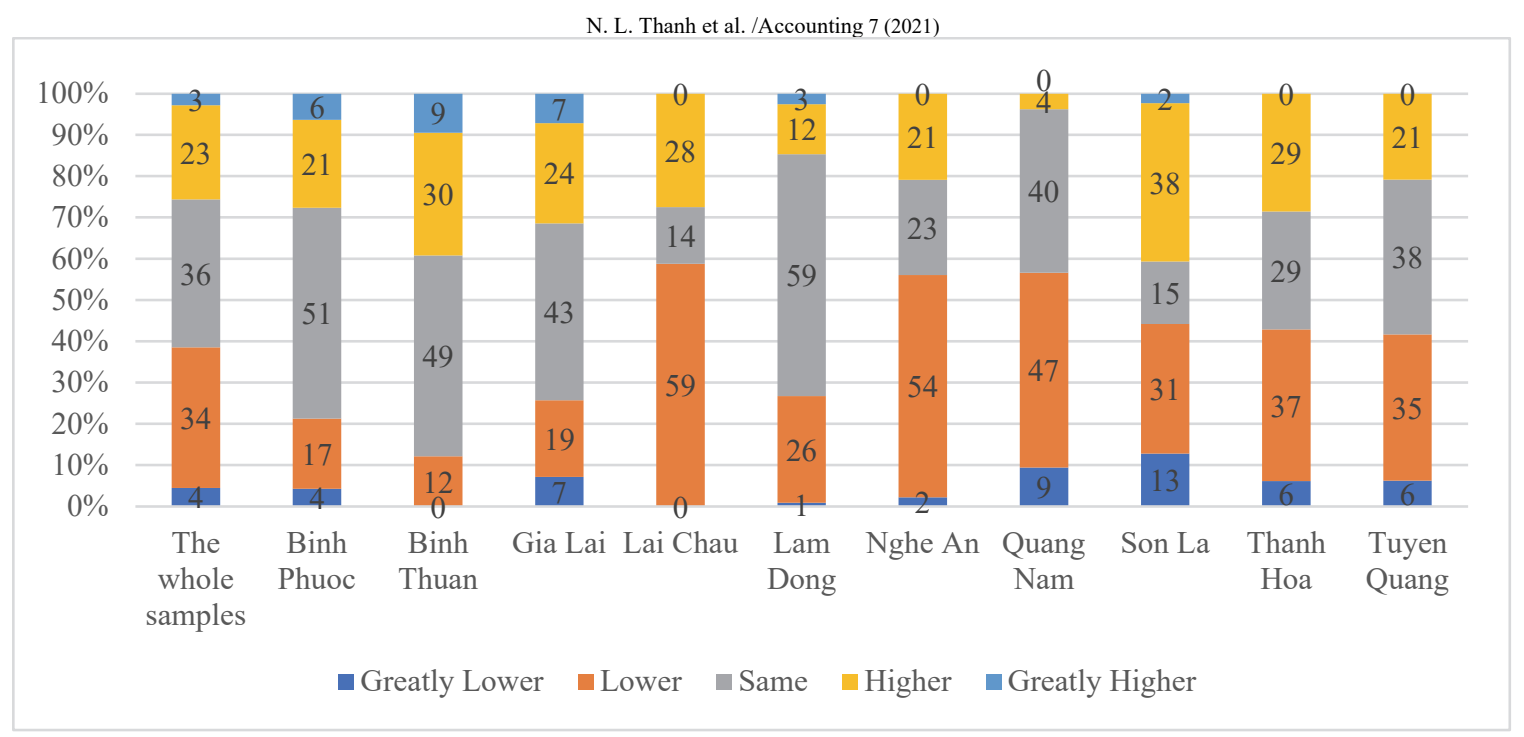

Fig. 1. Proportion of the impact assessment of the resettled households on their income by provinces

Source: Authors' calculation from the survey in 2018-2019

\subsection{The impact assessment estimated by the Propensity Score Matching model}

The statistical description of the factors affecting the income households, which are independent variables in the Logit model, is shown in Table 3. The t-test is also applied to identify if the difference between the two groups is significant or not. The significant result shows that resettled households have higher household member compared to unaffected on (4.948 people per household compared to 4.570 people); however, less proportion of household heads in working age ( $83.6 \%$ compared to $88.6 \%$ ), less agricultural land (1.987 ha compared to $3.630 \mathrm{ha}$ ), more saving proportion ( $7.7 \%$ compared to $2.9 \%)$, less borrowing ( $40.5 \%$ compared to $53.7 \%$ ), less investing in agriculture (37.2\% compared to $46.7 \%)$, having fewer production assets $(0.565$ assets per household compared to 0.717 ).

Table 3

The statistical description: Factors affecting the income households

\begin{tabular}{|c|c|c|c|c|c|}
\hline Independent variables & Unit & Resettled & Unaffected & Difference & p-value \\
\hline Household member & person & 4.948 & 4.570 & $0.378 * * *$ & 0.000 \\
\hline Education of household head & year & 1.490 & 1.574 & -0.084 & 0.142 \\
\hline Working age of household head & dummy & 0.836 & 0.886 & $-0.05 * * *$ & 0.004 \\
\hline Agricultural land & ha & 1.987 & 3.630 & $-1.644 * * *$ & 0.000 \\
\hline Saving & dummy & 0.077 & 0.029 & $0.048 * * *$ & 0.000 \\
\hline Loan & dummy & 0.405 & 0.537 & $-0.132 * * *$ & 0.000 \\
\hline Agricultural investment & dummy & 0.372 & 0.467 & $-0.095 * * *$ & 0.000 \\
\hline Numbers of household living assets & number & 5.244 & 5.283 & -0.039 & 0.819 \\
\hline Numbers of household production assets & number & 0.565 & 0.717 & $-0.152 * * *$ & 0.004 \\
\hline
\end{tabular}

Note: $*, * *, * * *$ indicate the significance level at 10\%, 5\%, 1\% levels, respectively.

Source: Authors' calculation from the survey in 2018-2019

This study will evaluate the resettlement impact on households through three outcome variables: total household income, income per capita, and agricultural income.

The Logit regression (more detailed in Appendix), which enables to calculate propensity score later, shows that there are 6 independent variables has a significant relationship with the fact that a household is resettled or unaffected; of which, 2 variables have a positive correlation (Household member and Saving), while 4 variables have a negative correlation (Agricultural land, Loan, Agricultural investment, and Numbers of household production assets). There is no detection of multicollinearity and heteroscedasticity phenomena among these variables.

The propensity score is estimated from the Logit model above. Regarding resettled households, the propensity score value ranges from 0.139 to 0.893 and the propensity score mean of this group is 0.514 . For the unaffected group, the propensity score value ranges from 0.177 to 0.858 and the mean is 0.448 . Thus, the common support of the two groups ranged from 0.139 to 0.858 . Inside the common support, there are 1,565 households, including 749 resettled households and 816 unaffected ones. Households inside the common support are matched along with three methods namely Nearest-neighbor (NN) matching, Kernel matching, and Radius matching. The most important point is that after performing the propensity score-based matching, the 
difference between the two groups will be more accurate. The Average Treatment Effect (ATE) will be calculated from the average of the difference in each matching pair, which is shown in Table 4.

\section{Table 4}

The income difference identified by the PSM model

\begin{tabular}{|c|c|c|c|c|c|c|c|}
\hline Outcome variables & Match & hod & Resettled & Unaffected & Difference & SE & t-test \\
\hline \multirow{4}{*}{$\begin{array}{l}\text { Total household income } \\
\text { (million VND/year) }\end{array}$} & Unmatching & & 60.230 & 66.113 & $-5.884 * *$ & 2.812 & 2.09 \\
\hline & \multirow[t]{3}{*}{ Matching } & $\mathrm{NN}$ & 60.261 & 73.316 & $-13.055 * * *$ & 5.048 & 2.59 \\
\hline & & Kernel & 60.261 & 69.020 & $-8.759 * * *$ & 3.027 & 2.89 \\
\hline & & Radius & 60.199 & 68.201 & $-8.002 * * *$ & 3.106 & 2.58 \\
\hline \multirow{4}{*}{$\begin{array}{l}\text { Income per capita } \\
\text { (million VND/person/year) }\end{array}$} & Unmatching & & 13.608 & 15.997 & $-2.388 * * *$ & 0.755 & 3.16 \\
\hline & \multirow[t]{3}{*}{ Matching } & $\mathrm{NN}$ & 13.611 & 16.632 & $-3.021 * *$ & 1.345 & 2.25 \\
\hline & & Kernel & 13.611 & 15.349 & $-1.738 * *$ & 0.811 & 2.14 \\
\hline & & Radius & 13.675 & 15.366 & $-1.691 * *$ & 0.834 & 2.03 \\
\hline \multirow{4}{*}{$\begin{array}{l}\text { Agricultural income } \\
\text { (million VND/year) }\end{array}$} & Unmatching & & 24.629 & 26.689 & -2.060 & 2.131 & 0.97 \\
\hline & \multirow[t]{3}{*}{ Matching } & $\mathrm{NN}$ & 24.668 & 23.982 & 0.686 & 3.764 & 0.18 \\
\hline & & Kernel & 24.668 & 24.978 & -0.310 & 2.300 & 0.13 \\
\hline & & Radius & 24.618 & 24.490 & 0.128 & 2.368 & 0.05 \\
\hline
\end{tabular}

Note: *, **, *** indicate significance at 10\%, 5\%, 1\% levels, respectively.

Source: Authors' estimation from the survey in 2018-2019

In NN and Kernel methods, the matching and comparison are conducted between 749 resettled households and 816 unaffected ones, but in the Radius method, the selection of 0.01 radius reduces the sample size to 714 resettled households and 816 unaffected ones. Because the propensity score distance within a matching pair is wider than 0.01 , the resettled observation will be considered as unmatchable.

The total household income: The NN-matching shows that the difference between the two groups is 13.1 million VND/year, while Kernel matching shows 8.8 million VND/year, and Radius matching shows 8.0 million VND/year. All of these results have a $1 \%$ level of significance. Thus, the resettlement influences negatively the households' income with a reduction from 8.0 - 13.1 million VND/year.

The income per capita: The NN-matching shows that the difference between the two groups is 3.0 million VND/person/year, while both Kernel and Radius matching show 1.7 million VND/person/year. All of these results have a 5\% level of significance. Thus, the resettlement influences negatively the income per capita with a reduction from $1.7-3.0 \mathrm{million} \mathrm{VND} / \mathrm{person} / \mathrm{year}$.

This result is similar to many other domestic and international studies related to resettlement such as Scudder (2011), Bui and Schreinemachers (2018), Kura, Joffre, Laplante, and Sengvilaykham (2014), which affirmed that the income increase only occurs in the first year after resettlement when the resettled people receive a great amount of compensation money. However, after that, the income will decline. In the other words, in the long term, the income of the resettlement households is highly unsustainable.

The agricultural income difference in all of the three matching methods is insignificant. It is word noting that agricultural income accounts for $40.8 \%$ of total income (resettled households) and 36.4\% (unaffected households), which implies that the difference in total income mostly caused by the difference in non-agricultural income.

\section{Conclusion and implications}

In general, the economic goal of the "new place is better than the old one" policy has not been achieved in many provinces. According to the Likert Scale, a large part of resettled households rated their income as reduced or unchanged compared to before. This disappointment is even very high in some provinces such as Lai Chau, Nghe An, and Quang Nam.

Through the PSM model, the study also demonstrated that the implementation of the resettlement policy resulted in an income reduction to the resettled households compared to the unaffected households. The household income gap of 8.0-13.1 million VND/year or income per capita gap of 1.7 - 3.0 million VND/person/year is highly considerable. Especially for the poor and pro-poor households, this gap is even equal to a high proportion of their income. It can be said that although the Government has issued many policies to ensure the living of resettled people, these actions have not brought much effectiveness.

It should be noted that although the resettled households have less agricultural land, the agricultural income between the two groups is not significant. Therefore, the well-known suggestion about giving more agricultural land for the resettled households for helping them to increase their income should be considered, because possibly this suggestion may not create an effective result as expected. Indeed, the average agricultural income around 24.6 million VND/year as the current is quite low and unable to contribute to improving the resettled households' living and eradicating their poverty sustainably. However, agricultural income still accounts for a large part of the resettled households' income structure, so it is still highly worth upgrading the agricultural sector in the resettlement area. Unfortunately, this article just focuses on impact assessment of resettlement on the 
income of ethnic minority households without analyzing opportunities to increase income, create jobs, and reduce poverty sustainably for these people, which need a greater effort into researching due to its complication and difficulties. In particular, the lack of qualified transport infrastructure systems that help to connect support services for commercial agricultural development, or the weak linkage between farmers and enterprises caused by unattractive investment into remote areas, which are hindering the production technology transfer and market connection for the resettled households, are all needed to be investigated carefully from a more comprehensive view. It is expected that in future researches this research gap will be sealed, which will highly contribute to helping the resettled people to attain a real better life.

\section{Acknowledgement}

The research team would like to express the deepest appreciation to National Council for Science and Technology Policy in 2016-2020 (CTDT/16-20) under Committee for Ethnic Minority Affairs who gave the funding for the project titled "The urgent issues in resettlement implementation for the ethnic minorities in Vietnam mountainous areas" and the data for implementing this article.

\section{References}

Baker, J. L. (2000). Evaluating the impact of development projects on poverty. In: The World Bank.

Becker, S. O., \& Ichino, A. (2002). Estimation of Average Treatment Effects Based on Propensity Scores. The Stata Journal: Promoting Communications on Statistics and Stata, 2(4), 358-377. doi:10.1177/1536867x0200200403

Bui, T. M. H., \& Schreinemachers, P. (2018). Livelihood changes of affected households under resource scarcity: The Son La hydropower project in Vietnam. Kasetsart Journal of Social Sciences. doi:10.1016/j.kjss.2018.08.004

Bui, T. M. H., Schreinemachers, P., \& Berger, T. (2013). Hydropower development in Vietnam: Involuntary resettlement and factors enabling rehabilitation. Land Use Policy, 31, 536-544. doi:10.1016/j.landusepol.2012.08.015

Caliendo, M. (2009). Start-up subsidies in East Germany: finally, a policy that works? International Journal of Manpower, 30(7), 625-647. doi:10.1108/01437720910997326

Caliendo, M., \& Kopeinig, S. (2008). SOME PRACTICAL GUIDANCE FOR THE IMPLEMENTATION OF PROPENSITY SCORE MATCHING. Journal of Economic Surveys, 22(1), 31-72. doi:10.1111/j.1467-6419.2007.00527.x

Committee for Ethnic Minority Affairs. (2014). Báo cáo về tình hình thực hiện chính sách hỗ trợ định canh định cư cho đồng bào dân tộc thiểu số từ năm 2008-2015 (Report on the implementation of sedentarization policies for ethnic minorities from 2008-2015).

Heinrich, C., Maffioli, A., \& Vazquez, G. (2010). A primer for applying propensity-score matching. Inter-American Development Bank.

Khandker, S., B. Koolwal, G., \& Samad, H. (2009). Handbook on Impact Evaluation: The World Bank.

Kura, Y., Joffre, O., Laplante, B., \& Sengvilaykham, B. (2014). Redistribution of water use and benefits among hydropower affected communities in Lao PDR. Water Resources and Rural Development, 4, 67-84. doi:10.1016/j.wrr.2014.09.001

Lã, V. L. (2009). Chính sách di dân, tái định cư phục vụ các công trình quốc gia ở vùng dân tộc và miền núi - những vấn đề cấp bách đặt ra cần giải quyết (Migration and resettlement policies from national projects in ethnic minority and mountainous areas - urgent problems). Tạp chi Dân tộ . Retrieved from

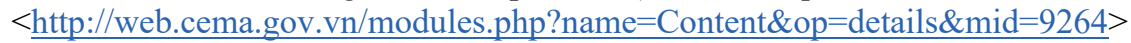

Likert, R. (1932). A technique for the measurement of attitudes. Archives of psychology.

Ministry of Agriculture and Rural Development. (2014). Báo cáo Kết quả thực hiện chính sách bồi thuờng, hồ trợ, tái định cư; thực trạng di dân, tái định cu các dụ án thủy lợi, thủy điện và đề xuất chính sách, nguồn lục thục hiện (Report on results of implementation of compensation, support and resettlement policies; current status of migration and resettlement for irrigation and hydropower projects and proposed policy and resources for implementation).

Ministry of Agriculture and Rural Development. (2017). Báo cáo Kết quả thục hiện công tác ổn định đời sống và sản xuất cho người dân tái định cu các dụ án thủy điện (Report on results of implementation of stabilization of life and production for resettled people in hydropower projects).

Ministry of Agriculture and Rural Development. (2020). Báo cáo Đánh giá tình hình thục hiện chính sách pháp luật về di dân, tái định cu các dụ án thủy lơi, thủy diện (Report on Assessment of implementation of legal policies on migration and resettlement for irrigation and hydropower projects).

Nguyễn, Đ. B. (2015). Chính sách đất đai về đất ở tái định cư nông thôn (Rural resettlement land policy). Hội Khoa học đất. Retrieved from <http://www.baoxaydung.com.vn/news/vn/quy-hoach-kien-truc/chinh-sach-dat-dai-ve-dat-o-tai-dinh-cunong-thon.html>

Nguyễ̂n, T. D., Đào, T. K., \& Từ, Q. P. (2016). Ảnh hưởng của các nhân tố chính sách tới kết quả TĐC: Nghiên cứu trường hợp dự án thủy điện Sơn La (Influence of policies on resettlement: The case study of Son La hydropower project). Kinh tế \& Phát triển, 233(2), 122-130.

Nguyễn, T. H. H. (2009). Thực trạng và giải pháp di dân tái định cư từ các công trình phát triển tài nguyên nước (Situation and solutions to relocation and resettlement from water resource development works). Tạp chí Khoa học kỹ thuật Thủy lợi và Môi Trưòng, 6(2009). 
Nguyễn Tiến Dũng, \& Đặng Khắc Ánh. (2016). Đánh giá hiệu quả của Chính sách Tái định cư ở Khu vực miền núi cho đồng bào dân tộc thiểu số (Evaluate the effectiveness of the Resettlement Policy in the Uplands for Ethnic Minorities). Tạp chí giáo dục lý luận, 247(6).

Nguyễn, T. M. P. (2014). Chính sách di dân tái định cư tại các dự án thủy điện trên địa bàn Nghệ An (Resettlement policy for hydropower projects in Nghe An province). Tạp Chí Khoa học và Công nghệ Nghệ An, 8(2014).

Nguyễn, V. Q., Nguyễn, T. V., Trang, H. D., \& Nguyễn, T. C. (2011). Công tác tái định cư dự án thủy điện Sơn La dưới góc độ phong tục tập quán canh tác của đồng bào dân tộc vùng Tây Bắc (Resettlement of Son La hydropower project under the perspective of farming practices of ethnic minorities in the Northwest). Tạp chí Khoa hoc và Phát triển, 9(6), 985-993.

Nhung, P. T.,, \& Thang, T. N. (2017). Changing Land Access of Resettled People Due to Dam Construction in Binh Thanh Commune. In Redefining Diversity \& Dynamics of Natural Resources Management in Asia, Volume 3 (pp. 53-68): Elsevier.

Phạm, S. L. (2015). Cần đồi mới chính sách tái định cư (Need to renew the resettlement policy). Tạp chí Tài Chính. Retrieved from $<$ http://tapchitaichinh.vn/thi-truong-tai-chinh/can-doi-moi-chinh-sach-tai-dinh-cu-94455.html $>$

Ravallion, M. (2001). The Mystery of the Vanishing Benefits: An Introduction to Impact Evaluation. The World Bank Economic Review, 15(1), 115-140. doi:10.1093/wber/15.1.115

Rosenbaum, P. R., \& Rubin, D. B. (1983). The central role of the propensity score in observational studies for causal effects. Biometrika, 70(1), 41-55. doi:10.1093/biomet/70.1.41

Scudder, T. (2011). Resettlement Outcomes of Large Dams. In Water Resources Development and Management (pp. 37-67): Springer Berlin Heidelberg.

Thanh, N. L. (2004). Báo cáo khảo sát, đánh giá kết quả công tác tái định cu, định canh cho đối tuợng đồng bào dân tộc thiểu số ở các công trình thủy điện (Qua một số điểm nghiên cứu khu vực miền Trung và Tây Nguyên) (Report on survey and assessment of the results of sedentarization policies for ethnic minorities in hydropower projects (Through some research sites in the Central and Central Highlands regions)). Vụ Chính sách dân tộc - CEMA và VP chương trình hợp tác XĐGN Việt Đức (GTZ-MOLIZA).

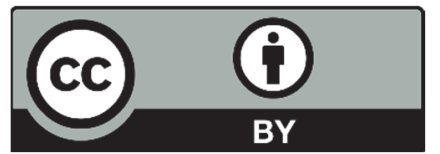

(C) 2021 by the authors; licensee Growing Science, Canada. This is an open access article distributed under the terms and conditions of the Creative Commons Attribution (CC-BY) license (http://creativecommons.org/licenses/by/4.0/). 